Application of Microseismic...

\title{
APPLICATION OF MICROSEISMIC MONITORING IN UNDERGROUND BLOCK CAVING MINE
}

\author{
Septian Prahastudhi, Achmad Muttaqi, Eric Sitorus, Erwin Riyanto, Farid Gumilang \\ Geoengineering Division, PT Freeport Indonesia \\ email : sprahast@fmi.com
}

\begin{abstract}
Abstrak. Aktifitas penambangan bawah tanah dapat memberikan dampak langsung terhadap stabilitas batuan. Tambang bawah tanah tipe block caving, memiliki beberapa area yang mana perkembangan dari garis cave /caveline dan muka terowongan/heading memberikan resiko untuk para pekerja yang bekerja di sekitar area tersebut. Massa batuan dalam jumlah yang besar dan kompak mampu memberikan gaya seperti tekanan yang mengenai lingkungan sekitarnya. Pergerakan lokal pada tambang bawah tanah yang sebagian besar disebabkan oleh aktivitas peledakan batuan, ataupun getaran pasif akibat massa batuan yang menemui kondisi tidak stabil menghasilkan gelombang $\mathrm{P}$ dan gelombang $\mathrm{S}$ yang merambat. Sistem pemantauan mikroseismik telah diterapkan pada suatu tambang bawah tanah aktif untuk menjamin keselamatan produksi. Makalah ini mendeskripsikan tentang aplikasi dari pemantuan mikroseismik secara real time pada suatu operasi tambang bawah tanah untuk mendukung keselamatan produksi.
\end{abstract}

Kata Kunci: pemantauan, mikroseismik, tambang block caving

\begin{abstract}
Induced mine activities could make impact to the rock's stability. Block cave mine has some area where development of the progressing cave line and heading are disturbing and having risk to harm people working in the surrounding area. Rock mass in massive solid rock generates movement in order acting the stress that applied in the environment. Local movement in the mine where it's caused by blasting - artificial source or passively occurs when the rock finds its stability is generating acoustic $P$ and $S$ waves. Microseismic monitoring system has been applied in the active mine area to ensure a safety production. This paper describes an application of real time microseismic monitoring system in underground mine operation to support a safety production.
\end{abstract}

Keywords : monitoring, microseismic, block caving mine

\section{INTRODUCTION AND BACKGROUND}

Running the underground mining activities, is a hard challenge for any parties that involved in the business. One of the biggest challenge is that the underground mine is a complex condition, whether in geology or geotechnical aspect. Hazard caused by seismicity such as major roof fall or rock burst always threatened the employee because it can lead into major injury or even fatality. Then, a method to prevent this is a must. Microseismic monitoring system is one of the key in preventing this type of hazard.

The traditional role of seismic analysis has been used to located the hypocenter and determine the size of earthquake or manmade tremors. Mining activity, has been recognized for over century as a cause of ground vibrations (Atkinson 1903).

Application of microseismic system to monitor underground mine activities has been used in many countries notably Australia, Canada, South Africa, UK and USA to monitor ground stability issues. An early evaluation of this technology by Obert and Duval in 1945, when a roof rock fractures or moves along a slip plane, its typically transmits the microseismic emission. Most of miners often noticed the association of popping or cracking noise with the fracturing of roof strata. Obert and Duval (1967) have long recognized that for every audible noise, there most likely occurs an equivalent multitude of microseismic events. Each of these emissions signifies the formation of a new rupture surface or slip on an existing fractures surface (Bajpayee et all, 2004).

The first technique that used to examine the seismic activities in mines was a device which can amplifying the signals in the audible range so that rock fracture activity could be observed in mines. More recently, Council for Scientific and Industrial Research use light emitting diodes mounted on a 
device that will flash when a preset number of events are sensed (Makusha and Minney, 2005).

In general, routine seismic monitoring enable the quantification of exposure to seismicity and provides a logistical tool to guide the effort into prevention, rating of seismic hazards and alerts to potential rock mass instabilities that could result in rock bursts. One can define the following five specific objectives of monitoring the seismic response of the rock mass mining (Mendecki et all, 1999).

1. Rescue: To detect and locate potentially damaging seismic events.

2. Prevention: To compare the observed and the expected seismic rock mass response to mining.

3. Seismic hazard rating: To quantify the exposures of seismicity and to monitor its spatial and temporal changes.

4. Alerts: To detect strong and unexpected changes in behavior of seismic parameters that could lead to instability.

5. Back analysis: To improve both mine design and the seismic monitoring processes.

With this important objectives, microseismic monitoring system has been a must to ensure the safety production (Lynch et all, 2010).

\section{GEOLOGICAL SETTING}

In this research we are focusing on an underground mine called DMLZ. The DMLZ underground mine started the operation in the middle of 2015 and estimated will be finish at 2041, it is a skarn deposition which located in the bottom of EEES (Ertsberg East Skarn System) and $500 \mathrm{~m}$ below another active underground mine called DOZ. This mine consist of several type of inner igneous rock or usually called as plutonic. The plutonic rocks that formed the deposition in this area is diorite. Beside of plutonic rock, it also consist of some sedimentary rocks such as Kais, Sirga, Faumai and Waripi formation. Another type of rocks that exist in this mines is altered rocks which a type of rock resulted from contact between igneous and sedimentary rocks such as skarn, hornfel, high alteration and low-grade ore. For the structure, at the production level, there are a complex structure, which is consist of 14 faults, NS2, NE7, NW8, NE6, NE5, NS4, NW7, NE4, NW8, NE3, NW5, NE2, NS1, NW6 and some other minor structure. This structures apparently triggered some seismic activities which surround them.

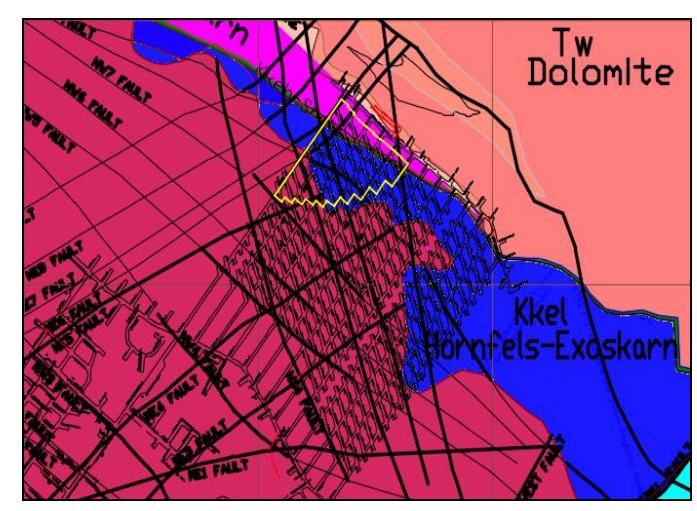

Figure 1. DMLZ mine geological setting

\section{MICROSEISMIC MONITORING SYSTEM IN DMLZ UNDERGROUND MINE}

In this research, we took an example for the application of microseismic monitoring in DMLZ underground mine, a deep hard rock mine located at Papua Province, Indonesia. The microseismic system is using ESG (Engineering Seismology Group). This system consist of 19 tri-axial geophone, installed in deep boreholes, 7 of them are uniaxial and the rest are tri-axial sensors. Sensor installation was completed around 3 years before the mine enter the production stage.

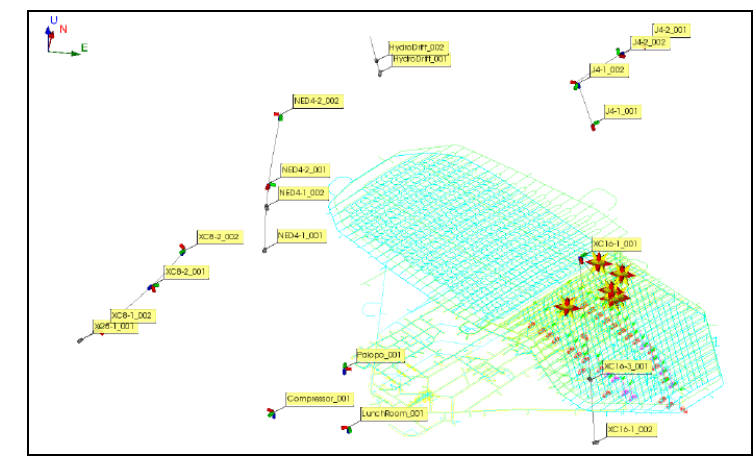

Figure 2. Microseismic monitoring system at DMLZ and the mine footprint. All of the sensors are located above the production area.

The ability of DMLZ microseismic system to monitor the seismic activities was performed with high confident after the blasting calibration. For calibration, we use 12 blast which the location already know very well. The calibration velocity model is shown to locate blast with RMS error of 
$15 \mathrm{~m}$, with the highest error in the vertical direction due to the location of the blast relative to the sensor location. The average distance is $26 \mathrm{~m}$ between calculated and known coordinates.

Hypocenter estimation in this system is using simplex algorithm which is use a solution from some of linear equation based on the time travel. By picking the P-wave and S-wave time arrival, the algorithm automatically find the minimum root mean square errors to find the source location.

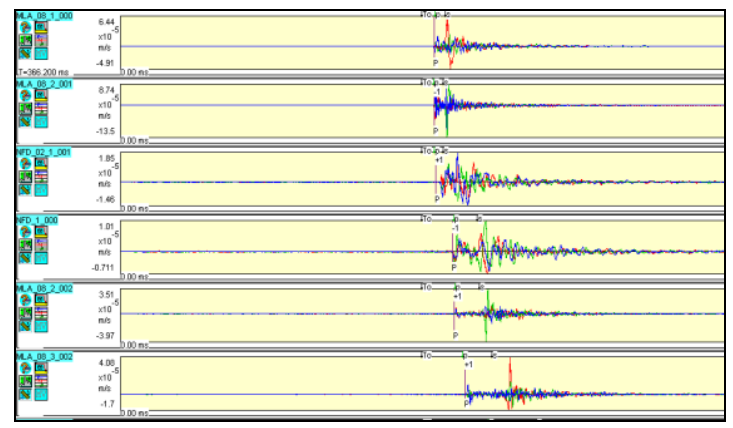

Figure 3. Seismic wave recording data at stations

\section{MICROSEISMIC AS TOOL IN CAVITY PROPAGATION PREDICTION}

In underground mine operation, the cavity always progress as the undercutting and mucking activity. In this case, the progression of the caving, lead the seismicity zone also progress. The seismic area, which still have more stress continue releasing energy which travel to the rocks until reach the sensors, when the area have no more energy to release, this area became an a-seismic zone, the seismogenic zone always progress in to area which have still energy to release. The location of a-seismic and seismogenic zone can lead us in to cave propagation determination and estimation.

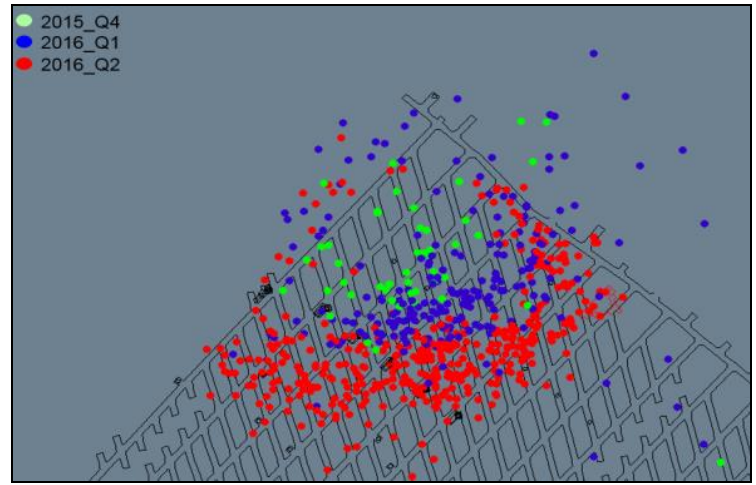

Figure 4. Microseismic events location as indication of cave propagation

Based on the figure above, it is clearly seen that the majority of seismic events locations is propagate through time, this caused by the caving itself is move larger impacted by mucking and blasting. In quarter 4 2015, the number of seismic events are 60, increasing the quarter 12016 become 225 events and become 414 in quarter 2 2016. This because of the widening of seismogenic zone as long as the cave itself become larger. From monthly basis, the trend of increasing in number of seismic events is more clearly.

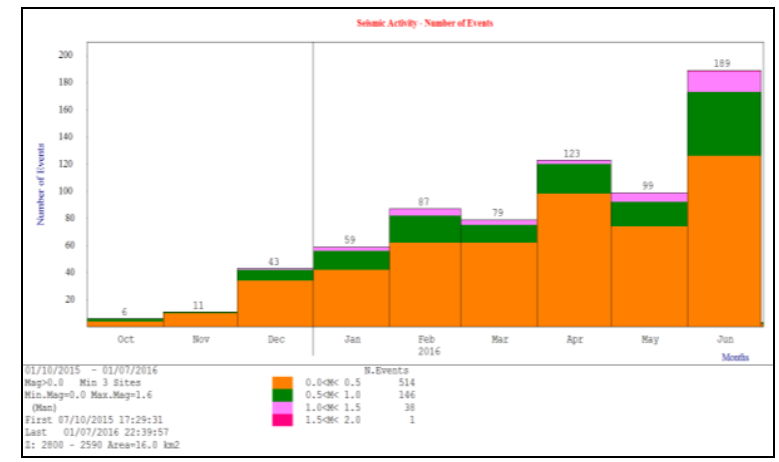

Figure 5. Number of microseismic events from mining start (October 2015) until June 2016 in monthly basis

\section{MICROSEISMIC - REENTRY PROTOCOL FOR ALERT AND PREVENTION}

Re-entry protocols are a tactical approach for controlling risk after blasts and large events in seismically active mines (Vallejos and McKinnon, 2009). In DMLZ mine, the re-entry protocols have been applied since early 2016, the objectives of this protocols is to prevent and alert the miners who work in potential damage area. A significant 
threshold has been determined from empirical data, resulted value of moment magnitude 0.7, which mean if an event with magnitude equal to or more than that, the miners must be evacuated in the safe area. Basically the 0.7 value is a conservative, historical data shows that seismic events which have 0.9 moment magnitude resulted a major damage in production level.

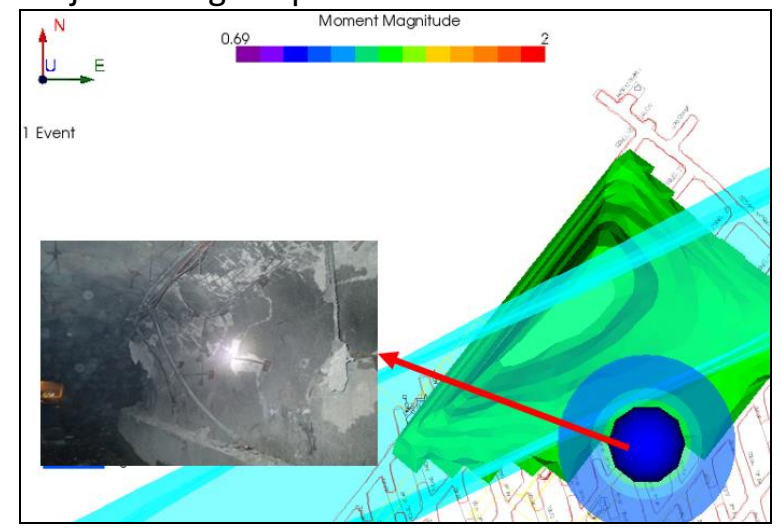

Figure 6. Major damage due to seismic event with 0.9 local magnitude, the distance between damage area and the seismic hypocenters is $30 \mathrm{~m}$.

Beside from the significant seismic activity, another type of seismic activities can also activate the re-entry protocol based on the events rate in an hour. Based on the events rate background and historical data, if number of seismic events with moment magnitude more than -0.3 equals or more than 3 in an hour, then the miners have to evacuate.

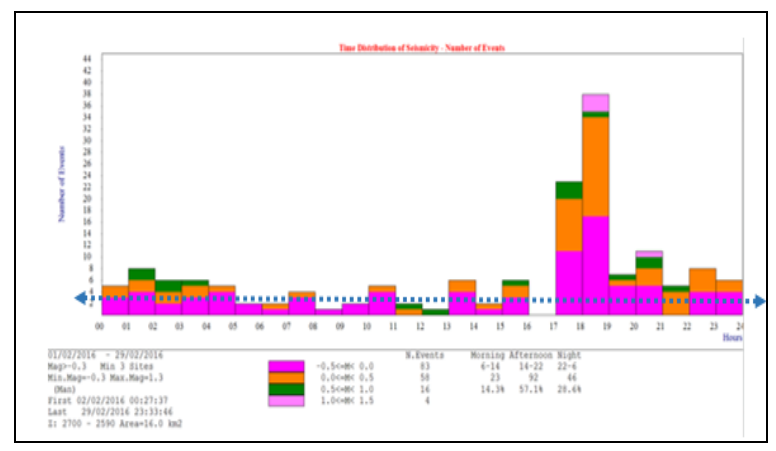

Figure 7. Number of average seismic events rate in a day with magnitude $>-0.3$, blue dotted line indicated the background of seismic activities.

From the picture above, the blue dotted line indicated the number of background of seismicity which is 2 events/h. The highly events rate at around 6:00PM and after, was caused by blasting activity at the end of the dayshift.

\section{MICROSEISMIC AS BACK ANALYSIS}

Back analysis is necessary to understand how the rock mass behave related with the seismic activities. Following the re-entry protocol that ran in DMLZ, some of the significant event surely create new damage but some of them also did not show any damage, it is make sense because the threshold from the protocol is the conservative value.

There are so many seismic parameters that can be used to analyze the rock mass behavior, some analysis based on the seismic moment and seismic source energy has been performed to understand the seismic characterization in a weekly interval related to the damage. Based on those parameter, the relation between seismic moments related to energy can be found.

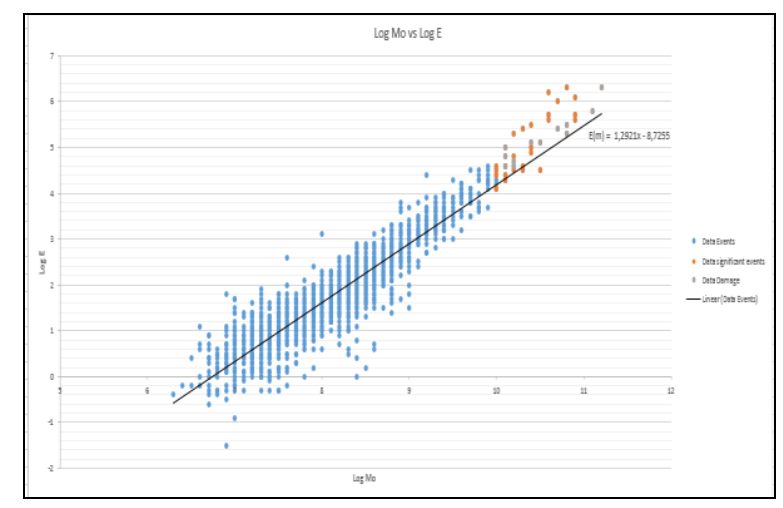

Figure 8. Relation between seismic moment and energy

Graph of the relation between seismic moment and energy shows that events which located in the zone B are classified as event with damage potential. The significant events always have seismic moment equal or more than $10 \mathrm{GNm}$. Then, threshold based on the seismic moment and seismic energy can be derived. Damage will be happen if the seismic moment $\geq 10 \mathrm{GNm}$ and seismic energy $\geq 10^{4.2}$ Joule.

Some case related this analysis have shown a good result. One damage that occur on February $1^{\text {st }}$ 2016, then we interpolate the recorded seismic events in 3D model to get the seismic parameters in all area. The result shows that damage is located in the seismic area which the seismic moment and energy are above the threshold. 

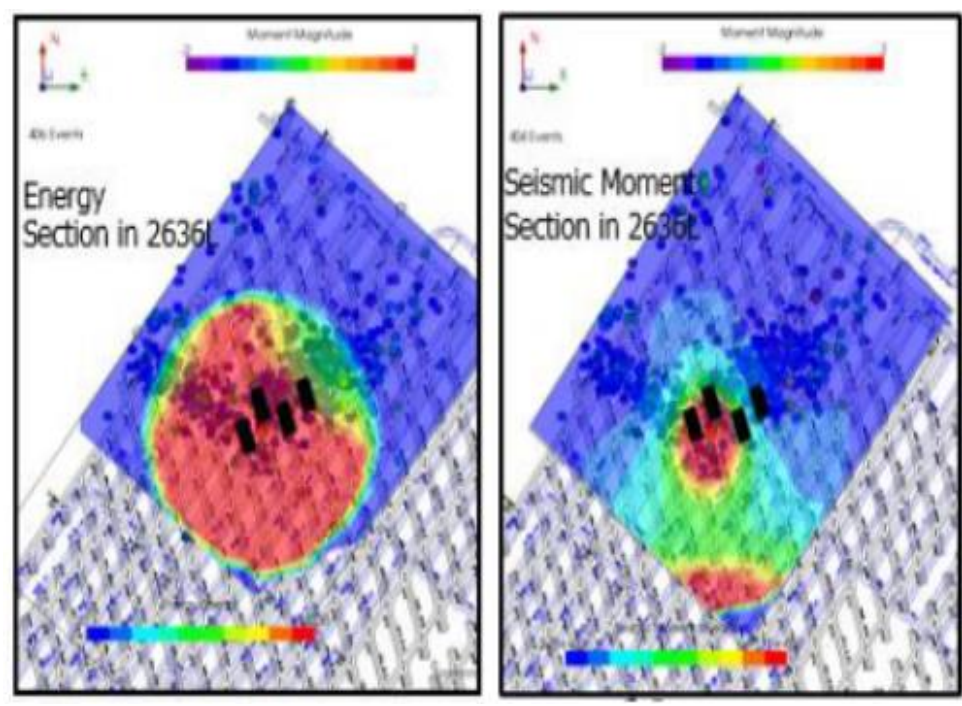

Figure 9. Seismic moment and Energy section, black line identified the damages location

The energy section clearly shown that all the damages are located inside the red zone (zone with energy $\geq 10^{4.2}$ Joule, but from the seismic moment section, 1 damage located outside its red zone. This probably caused that the shear modulus model that use for the seismic moment calculation is isotropic.

\section{CONCLUSIONS}

Microseismic monitoring system is a powerful tool to support the safe production in mining activities. Cavity progress can be detected with the seismic events location analysis, safety of the miners can be ensure with the re-entry protocol which can only derived from microseismic system, and also it can be used to analyze the rock mass behavior related the mining activities. But, a lot of analysis must still be performed to get a better result such as using the anisotropic model.

\section{ACKNOWLEDGEMENT}

A great full thanks announced to Mr. Arjuna Ginting and all of the colleges in UG Geotech \& Hydrology department, PT Freeport Indonesia.

\section{REFERENCES}

Atkinson, W. N (1903), "Report of H.M Inspector of Mines for the Stafford District for the year 1903.

Baypajee, T. S., lannacchione, A. T and Schilling, S. R (2008), "Detecting Strata Fracturing and Roof Failures from Borehole Based Microseismic System", $27^{\text {th }}$ International Conference on Ground Control in Mining, pp. 313-318.

Lynch, R. A., Mendecki, A. J and D. Malovickho (2010), "Routine Microseismic Monitoring in Mines", Australian Earthquacke Engineering Society Conference, pp. 1-33.

Makusha, G and D. Minney (2005), "A System to Provide Early Warning on Impending Goaf", $24^{\text {th }}$ International Conference on Ground Control in Mining, pp. 61-65.

Mendecki, A. J., G van Aswegwn, and P. Mountfort (1999), "A Guide to Routine Seismic Monitoring in Mines, in A Handbook on Rock Engineering Practice for Tabular Hard Rock Mines", edited by A. J. Jager and J. A. Ryder, The Safety in 
Mines Research Advisory Committee, Johannesburg, pp. 287-309.

Obert, L and W. I. Duval (1945), "The Microseismic Method of Predicting Rock Failure in Underground Mining, Part 1, General Method, "Bureau of Mines, Report of Investigation 3797.

Obert, L and W. I. Duval (1967), "Rock Mechanics and the Design Structures in Rock". John Wiley and Sons, Inc., New York, NY, pp. 113-118.

Vallejos, J. A and S. M. McKinnon (2009), "Re-Entry Protocols for Seismically Active Mines Using Statistical Analysis of Aftershock Sequences", Proceeding of the $3^{\text {rd }}$ CANUS Rock Mechanic Symposium, paper 4028 . 